\title{
Outcomes of surgical management of intracerebral hemorrhagic stroke at a tertiary care center in Yogyakarta, Indonesia
}

\author{
Rahmat Andi Hartanto*, Teuku Jauhardin \\ Neurosurgery Division, Department of Surgery, Faculty of Medicine,Public Health and \\ Nursing, Universitas Gadjah Mada /Dr. Sardjito General Hospital, Yogyakarta, Indonesia \\ DOI: http://dx.doi.org/10.19106/JMedScie/0050032018010
}

\section{ABSTRACT}

Hemorrhagic stroke remains a significant cause of morbidity and mortality worldwide. However, the role of surgical treatment for hemorrhagic stroke remains controversial. Previous studies had proposed surgery can prevent herniation, lowering intracranial pressure (ICP) and reducing mass effect and cellular toxicity. Outcome in previous studies are conflicting. Studies concerning outcomes of surgical management of hemorrhagic stroke in Indonesia are limited. This study aimed to compare the outcome of hemorrhagic stroke treatment between surgical evacuation and conservative management in Dr. Sardjito General Hospital, Yogyakarta, Indonesia. Retrospective cohort study was conducted. Eighty spontaneous intracerebral hemorrhagic $(\mathrm{ICH})$ stroke patients involved in this study during January 2014 to August 2015. Of whom 36 (45\%) male and $44(55 \%)$ female. There were 45 and 35 patients underwent surgical treatment and conservative management, respectively. Surgical treatment group survival was $74 \%$, whereas the survival in the conservative group was $26 \%$. There was a statistically significant difference between surgery group and conservative group ( $p<0.001$; Cl 95\% 2.24-15.69). Furthermore, there was association of GCS less than 8 , high systolic BP, intraventricullar hemorrhage (IVH) and length of stay (LOS) with poor outcome. Analysis also showed surgical treatment, lower GCS score and hypertension associate with unfavorable Glascow outcome scale (GOS). In conclusion, patients with hemorrhagic stroke who are surgically indicated might have an advantage of hematoma evacuation and better outcome.

\section{ABSTRAK}

Stroke perdarahan masih merupakan penyebab signifikan morbiditas dan mortalitas di seluruh dunia. Kaidah pembedahan terhadap kebanyakan pasien stroke perdarahan masih dianggap kontroversial. Teori rasional untuk evakuasi hematoma berpatokan pada konsep prevensi herniasi, menurunkan tekanan intrakranial, dan menurunkan dampak hematoma pada jaringan sekitarnya dengan mengurangi efek massa atau toksisitas seluler. Penelitian yang menganalisis hasil penanganan pasien stroke perdarahan di pusat pelayanan bedah saraf di Indonesia masih terbatas. Penelitian ini bertujuan untuk menganalisis hasil penanganan pasien stroke perdarahan yang menjalani terapi pembedahan atau konservatif di Rumah Sakit Umum Pusat (RSUP) Dr. Sardjito. Penelitian ini merupakan penelitian kohort retrospektif yang membandingkan hasil klinis pada pasien stroke perdarahan yang menjalani pembedahan dan tidak di RSUP Dr. Sardjito, yang merupakan pusat rujukan kasus stroke perdarahan di provinsi DI Yogyakarta dari bulan Januari 2014 sampai dengan Agustus 2015. Dilakukan analisis terhadap data pasien meliputi umur, jenis kelamin, Glascow outcome scale (GOS), penanganan dan hasil dari penanganan yang diberikan. Pengumpulan data dilakukan di Instalasi Catatan Medis RSUP Dr. Sardjito. Dari 45 pasien yang dilakukan operasi, 74\% pasien selamat. Dari 35 pasien yang diindikasikan untuk dilakukan operasi, tetapi tidak menjalani operasi, $26 \%$ pasien selamat. Terdapat hubungan yang bermakna antara terapi bedah dengan hasil klinis ( $p$ 
$<0,001$; CI 95\%: 2,24-15,69). Terdapat hubungan antara nilai GCS kurang dari 8, tingginya tekanan darah sistolik, perdarahan intraventrikular dan lama perawatan terhadap keluaran yang lebih buruk. Terdapat hubungan juga antara terapi bedah, GCS rendah, dan tekanan darah sistolik terhadap nilai GOS yang lebih buruk. Dapat disimpulkan bahwa pasien dengan stroke hemoragik yang diindikasikan dengan pembedahan kemungkinanmemiliki keuntungan evakuasi hematoma dan hasil yang lebih baik.

Keywords: intracerebral hemorrhagic stroke - surgical treatment - conservative management - outcomes

\section{INTRODUCTION}

Stroke remains a leading cause of morbidity and mortality around the world. There are two types of stroke, i.e. ischemic (non-hemorrhagic) stroke and hemorrhagic stroke. Over $80 \%$ of stroke are nonhemorrhagic type, hemorrhagic stroke only accounted $15-22 \%$ of all mortality caused by stroke. ${ }^{1}$ Regardless of the small percentage, the hemorrhagic stroke has higher mortality rate than ischemic stroke. The role of surgical evacuation for hemorrhagic stroke remains controversial. The rational theory for the evacuation of hematoma based on the concept of prevent herniation, lowering the intracranial pressure and prevent the pathophysiology of hematoma impact on the surrounding tissue by reducing the effects of cellular toxicity mass or blood products. ${ }^{2-4}$

In previous studies, the outcomes of stroke treatment are inconsistent. Randomized controlled trials comparing surgical treatment with conservative treatment showed no significant benefit. Two prospective randomized controlled trials, and three meta analysis to compare the outcomes between conservative treatment and surgical treatment of intracerebral hemorrhage (ICH) also showed similar results. Randomized trials to compare between surgery and conservative management did not demonstrate a clear benefit for surgical intervention. Moreover, the generalizability of the results of these trials can be questioned, because patients at risk for herniation were likely excluded and the largest and most recent studies had high rates of treatment group crossover from conservative management to surgery. ${ }^{2}$
Studies concerning the outcomes of surgical management of hemorrhagic stroke in Indonesia are limited. This study aimed to compare the outcomes of intracerebral hemorrhagic stroke treatment between surgical evacuation and conservative management in Dr. Sardjito Hospital, Yogyakarta, Indonesia.

\section{MATERIALS AND METHODS}

\section{Subjects}

This was a retrospective cohort study comparing of the clinical outcome of intracerebral hemorrhagic stroke patients who underwent surgery and conservative treatment in the Department of Neurosurgery, Dr. Sardjito General Hospital, Yogyakarta, Indonesia, within the period of January 2014 to August 2015. Data were collected form patient's medical record. Patient's sociocemographic and clinical characteristics, the therapy, and follow up of their outcome were collected. After treatment, patient's outcome (recover or death), length of stay and Glasgow outcome scale (GOS) were identified.

Patients included in the study were patients who diagnosed with spontaneous ICH. Patients with subarachnoid hemorrhage or traumatic ICH were excluded in this study. Patients who were surgically indicated but the family refused to do were considered as conservative management group.

\section{Protocol}

To compare sociodemographic characteristics of ICH patients, the gender, age, area of residence were identified 
(TABLE 1). Patients were divided by gender (male and female), age at the time of admission and area of residence (same area as the medical institution or other area).

Clinical characteristics are factors related to medical treatment received by the patients; and included diagnosis, whether surgery was performed, initial blood pressure and Glasgow coma scale (GCS), and length of stay (LOS). Glasgow outcome scale (GOS) were examined after discharge from hospital when patients went to follow up to hospital. Nontraumatic intracerebral hemorrhage (I61.0-I61.9) were classifiable under ICD-10 codes. Surgery was classified as "performed" in case in which there was a recorded day of a main operation that was performed clearly for treatment purposes and not for diagnostic or exploratory purposes or to treat complications (the organization for economic cooperation and development also classifies medical and surgical categories based on whether surgery is performed). The length of stay was calculated by counting the number of days that passed between admission and discharge days.

TABLE 1 Variable observed of ICH patients

\begin{tabular}{|c|c|c|}
\hline Variable & \multicolumn{2}{|c|}{ Measure } \\
\hline \multicolumn{3}{|l|}{ Independent Variable } \\
\hline \multicolumn{3}{|l|}{ Sociodemographic } \\
\hline - Sex & 0. Male & 1. Female \\
\hline - Age & Patient's age & \\
\hline - Area & 0. Same & 1. Other \\
\hline \multicolumn{3}{|l|}{ Clinical characteristics } \\
\hline - Management & 0. Surgery & 1. Conservative \\
\hline - Length of stay & \multicolumn{2}{|c|}{ Days stay in hospital } \\
\hline - Diagnosis & $0 . \mathrm{IVH}$ & 1. other \\
\hline - Hypertension & 0. Yes & 1. No \\
\hline - Glasgow coma scale (GCS) & $0 . \leq 8$ & 1. $>8$ \\
\hline Dependent Variable & & \\
\hline - Outcome & 0. Recover & 1. Death \\
\hline - Glasgow outcome scale (GOS) & 0. Favorable & 1. Unfavorable \\
\hline
\end{tabular}

\section{Statistical analysis}

The $\mathrm{t}$ test and Chi-square test were performed for comparative analysis of ICH patient characteristics such as sociodemoraphics, clinical conditions and managements, depending on outcome of treatment as recover or death and GOS, divided into favorable (GR/MD) or unfavorable (SD/V/D) outcome. Log transformation was performed for the systolic $\mathrm{BP}$ and LOS, as the average and median values exhibited asymmetric distribution. The level of significant was set as $p<0.05$. Statistical analysis was performed using
SPPS for Windows version 24.

\section{RESULTS}

A total 83 patients were recruited between January 2014 to August 2015. Among 83 stroke patients, the majority had ICH ( 80 or $96 \%$ ), followed by subarachnoid hemorrhage (SAH) (2 or 3\%) and malignant neoplasm of cerebrum (1 or 1\%). Only patients diagnosed with IHC were included, so total sample analysed was 80 patients. TABLE 2 shows the frequency of sample based on hospitalization period and TABLE 3 summarizes all characteristics measured. 
TABLE 2. Number of sample data based on hospitalization period

\begin{tabular}{lcc}
\hline Period & Frequency & (\%) \\
\hline January-December 2014 & 45 & 54.2 \\
January-August 2015 & 38 & 45.8 \\
Total & 83 & 100 \\
\hline
\end{tabular}

TABLE 3. Characteristics of patients

\begin{tabular}{lccc}
\hline Variable & $\mathrm{N}$ & $\%$ & CI 95\% (\%) \\
\hline Sex & & & \\
- Male & 36 & 45 & $34.1-55.9$ \\
- Female & 44 & 55 & $44.1-65.9$ \\
Age (mean \pm SD years) & $59.4 \pm 13.51$ & $56.4-62.3$ \\
Province & & & \\
- Yogyakarta & 62 & 76 & $66.6-85.3$ \\
- Central Java & 14 & 18 & $6.4-21.6$ \\
- East Java & 2 & 3 & $-0.7-6.7$ \\
- West Java & 1 & 2 & $-1.1-5.1$ \\
- Unknown & 1 & 1 & $-1.2-3.2$
\end{tabular}

Therapy

- Surgery

$45 \quad 56 \quad 45.1-66.8$

- Conservative

$35 \quad 44 \quad 33.1-54.8$

Outcome

- Recover

$\begin{array}{lll}46 & 58 & 47.1-68.8\end{array}$

- Death

$34 \quad 42$

$31.2-52.8$

Length of stay (mean \pm SD days)

$12.9 \pm 9.87$

$10.7-15.0$

Diagnosis

- ICH unspecified

$\begin{array}{lll}46 & 58 & 47.1-68.8\end{array}$

- ICH intraventricular

$19 \quad 24 \quad 14.6-33.4$

- ICH hemisphere

$9 \quad 11$

4.1-17.9

- ICH multiple localized

$\begin{array}{lll}4 & 5 & 0.2-9.8\end{array}$

- ICH cerebellum

22

$-1.1-5.1$

Glasgow Coma Scale

- $\leq 8$

$54 \quad 68$

57.8-78.2

- $>8$

$26 \quad 32$

$21.8-42.2$

Blood pressure (mean $\pm \mathrm{SD} \mathrm{mmHg}$ )

- Systole

$153.4 \pm 11.88 \quad 150.8-156.0$

- Diastole

$87.6 \pm 6.79$

$86.1-89.1$

Hypertension (>140 mmHg)

- Yes

$\begin{array}{lll}62 & 78 & 68.9-87.1\end{array}$

- No

$\begin{array}{lll}18 & 22 & 12.9-31.1\end{array}$

Glasgow outcome scale (GOS)

- Favorable

$32 \quad 40 \quad 29.3-50.7$

- Unfavorable

$\begin{array}{lll}48 & 60 & 46.3-70.7\end{array}$


TABLE 4 shows in ICH patients, surgical treatment group had better outcome than conservative group $(p<0.001)$. Compared with patients who survived, died patients showed higher initial systolic BP $(p=0.009)$, poorer initial lower GCS ( $p<0.001)$, shorter LOS $(p<0.001)$ and had slighty different outcome whether diagnosis was ICH with IVH or other ICH ( $p=0.03)$. Similarly, when compared with favorable GOS scoring, surgical treatment had better recovery outcome than conservative treatment $(p<0.001)$, lower GCS score $(p<0.001)$ and higher initial systolic BP $(p=0.03)$.

TABLE 4. Outcome of hemorrhagic stroke treatment between surgical evacuation and conservative management

\begin{tabular}{|c|c|c|c|c|c|c|c|c|}
\hline \multirow[b]{2}{*}{ Variable } & \multicolumn{4}{|c|}{ Outcome } & \multicolumn{4}{|c|}{ GOS } \\
\hline & $\begin{array}{l}\text { Recover } \\
(\mathrm{n}=46)\end{array}$ & $\begin{array}{l}\text { Death } \\
(\mathrm{n}=36)\end{array}$ & $\mathrm{p}$ & OR/MD (CI 95\%) & $\begin{array}{c}\text { Favorable } \\
(\mathrm{n}=32)\end{array}$ & $\begin{array}{l}\text { Unfavorable } \\
\quad(\mathrm{n}=48)\end{array}$ & $\mathrm{p}$ & OR/MD (CI 9 5\%) \\
\hline \multicolumn{9}{|l|}{ Sex* } \\
\hline - Male & 18 & 18 & \multirow{2}{*}{0.220} & \multirow{2}{*}{$0.57(0.23-1.40)$} & 12 & 24 & \multirow{2}{*}{0.270} & \multirow{2}{*}{$0.60(0.24-1.49)$} \\
\hline - Female & 28 & 16 & & & 20 & 24 & & \\
\hline $\begin{array}{l}\text { Age } \\
(\text { mean } \pm \mathrm{SD} \mathrm{mmHg})^{* *}\end{array}$ & $57.67 \pm 13.02$ & $61.62 \pm 14.02$ & 0.190 & $-3.94(-10.00-2.12)$ & $58.00 \pm 13.77$ & $60.25 \pm 13.41$ & 0.470 & $-2.25(-8.46-3.96)$ \\
\hline \multicolumn{9}{|l|}{ GCS* } \\
\hline - $\leq 8$ & 20 & 34 & \multirow{2}{*}{$<0.001$} & \multirow{2}{*}{$0.37(0.26-0.52)$} & 7 & 47 & \multirow{2}{*}{$<0.001$} & \multirow{2}{*}{$0.006(0.001-0.051)$} \\
\hline - $>8$ & 26 & 0 & & & 25 & 1 & & \\
\hline $\begin{array}{l}\text { Systole } \\
(\text { mean } \pm \mathrm{SD} \mathrm{mmHg})^{* *}\end{array}$ & $15.43 \pm 10.55$ & $157.32 \pm 12.56$ & 0.009 & $-6.88(-12.04--1.73)$ & $\begin{array}{l}149.94 \quad \pm \\
10.31\end{array}$ & $155.65 \pm 12.41$ & 0.034 & $-5.70(-10,98--0.43)$ \\
\hline \multicolumn{9}{|l|}{ Diagnosis* } \\
\hline - IVH & 7 & 12 & \multirow{2}{*}{0.037} & \multirow{2}{*}{$0.33(0.11-0.96)$} & 4 & 15 & \multirow{2}{*}{0.054} & \multirow{2}{*}{$0.31(0.09-1.06)$} \\
\hline - Other & 39 & 22 & & & 28 & 33 & & \\
\hline $\begin{array}{l}\mathrm{LOS} \\
(\text { mean } \pm \mathrm{SD} \text { days })^{* *}\end{array}$ & $17.24 \pm 10.12$ & $7.09 \pm 5.68$ & $<0.001$ & $10.15(6.31-13.99)$ & $13.13 \pm 4.29$ & $12.79 \pm 12.31$ & 0.860 & $0.33(-3.53-4.19)$ \\
\hline \multicolumn{9}{|l|}{ Therapy* } \\
\hline - $\quad$ Surg & 34 & 11 & \multirow{2}{*}{$<0.001$} & \multirow{2}{*}{$5.92(2.24-15.69)$} & 26 & 19 & \multirow{2}{*}{$<0.001$} & \multirow{2}{*}{$6.61(2.29-19.08)$} \\
\hline - Cons & 12 & 23 & & & 6 & 29 & & \\
\hline
\end{tabular}

*: $\mathrm{X}^{2}$ analysis; **: t-test analysis; GCS: glasgow coma scale; LOS: length of stay; Surg: surgery; Cons: conservative; SD: standard deviation; IVH: intraventricular hemorrhage; GOS: Glasgow outcome scale; OR: odds ratio; MD: mean difference

TABLE 5 shows whether surgery was done or not, GCS score less than 8 tend to got surgery than GCS score more than 8 (p $=0.002)$. There were no association between sex, age, systolic BP and LOS with treatment choices for patients. Moreover, there were no association between sex, age, GCS, systolic $\mathrm{BP}$ and LOS with wether diagnosis was ICH with or without IVH. 
TABLE 5. Factors associated with therapy and diagnosis

\begin{tabular}{|c|c|c|c|c|c|c|c|c|}
\hline \multirow[b]{2}{*}{ Variable } & \multicolumn{4}{|c|}{ Therapy } & \multicolumn{4}{|c|}{ Diagnosis } \\
\hline & $\begin{array}{l}\text { Surgery } \\
(\mathrm{n}=45)\end{array}$ & $\begin{array}{l}\text { Conservative } \\
\quad(\mathrm{n}=35)\end{array}$ & $\mathrm{p}$ & OR/MD (CI 95\%) & $\begin{array}{l}\text { IVH } \\
(n=19)\end{array}$ & $\begin{array}{l}\text { Other } \\
(\mathrm{n}=61)\end{array}$ & $\mathrm{p}$ & OR/MD (CI $95 \%)$ \\
\hline \multicolumn{9}{|l|}{ Sex $^{*}$} \\
\hline - Male & 17 & 19 & \multirow{2}{*}{0.140} & \multirow{2}{*}{$0.51(0.21-1.25)$} & 12 & 24 & \multirow{2}{*}{0.068} & \multirow{2}{*}{$2.64(0.91-7.66)$} \\
\hline - Female & 28 & 16 & & & 7 & 37 & & \\
\hline $\begin{array}{l}\text { Age } \\
(\text { mean } \pm \mathrm{SD} \text { mmHg) })^{* *}\end{array}$ & $60.82 \pm 14.46$ & $57.46 \pm 12.13$ & 0.272 & $3.36(-2.56-9.28)$ & $61.05 \pm 12.96$ & $58.82 \pm 13.72$ & 0.533 & $2.23(-4.81-9.27)$ \\
\hline \multicolumn{9}{|l|}{ GCS* } \\
\hline - $\leq 8$ & 24 & 30 & \multirow{2}{*}{0.002} & \multirow{2}{*}{$0.19(0.06-0.58)$} & 16 & 28 & \multirow{2}{*}{0.075} & \multirow{2}{*}{$3.23(0.85-12.30)$} \\
\hline - $>8$ & 21 & 5 & & & 3 & 23 & & \\
\hline $\begin{array}{l}\text { Systole } \\
(\text { mean } \pm \mathrm{SD} \mathrm{mmHg})^{* *}\end{array}$ & $152.69 \pm 12.35$ & $154.23 \pm 11.38$ & 0.569 & $-1.54(-0.68-3.82)$ & $148.95 \pm 10.34$ & $154.74 \pm 12.07$ & 0.063 & $-5.79(-11.54--0.40)$ \\
\hline $\begin{array}{l}\mathrm{LOS} \\
(\text { mean } \pm \mathrm{SD} \text { days })^{* *}\end{array}$ & $14.44 \pm 8.83$ & $10.97 \pm 10.87$ & 0.119 & $3.47(-0.91-7.86)$ & $13.11 \pm 11.41$ & $12.87 \pm 9.44$ & 0.928 & $0.24(-4.95-5.43)$ \\
\hline
\end{tabular}

\section{DISCUSSION}

In this study, we found a better outcome (reduce mortality and better GOS) in hemorrhagic stroke patients underwent surgery compared to those who were conservatively managed. For over 50 years, there have been clinical trials of surgical clot evacuation aimed at reducing the mass effect. ${ }^{5,6}$ Since the first clinical trial of surgical ICH evacuation ${ }^{5}$, there have been multiple small trials but the result was conflicting. ${ }^{6}$ To clarify this, large surgical trial (the Surgical Trial in Intercerebral Hemorrhage (STICH) trial, $n=1033$ ) have been conducted, but failed to demonstrate any benefit of clot evacuation. ${ }^{7}$ Sub-analysis of the STICH I trials results indicated that superficial hematoma $(<1 \mathrm{~cm}$ from cortical surface) lobar hemorrhage might benefit from clot evacuation, perhaps because reducing surgical trauma than deep hemorrhage patients. Additional subgroup analysis suggested that the risk for a poor outcome was increased for patients who presented as comatose (GCS score $\leq 8){ }^{2}$

The STICH II trial addressed the question of whether early surgery would be beneficial for conscious patients with superficial lobar hemorrhage of 10 to 100 $\mathrm{mm}^{3}$ within $1 \mathrm{~cm}$ of the cortical surface and without IVH and who were admitted within 48 hours of ictus. STICH II trial resulted again no evidence of significantly improved outcome compared to medical treatment. ${ }^{8}$

However, recent report, American Heart Association/American Stroke Association (AHA/ASA) guideline for spontaneous ICH management 2015 has suggested a possible role for craniectomy in ameliorating increased ICP caused by $\mathrm{ICH} .{ }^{2}$ The guideline suggest that surgery give benefit for preventing herniation, reducing ICP and decreasing the pathophysiological impact of the hematoma on surrounding tissue by decreasing mass effect or the cellular toxicity of blood products. Whether surgery has the benefit on ICH still controversial, other approaches currently being tested use minimally invasive surgery in combination with hematoma lysis methods. In the minimally invasive surgery plus rtPA for intercerebral hemorrhage evacuation (MISTIE) trial (NCT00224770), a minimally invasive approach is being used with t-PA to assist evacuation ${ }^{9}$ and this has recently been reported to reduce perihematomal edema. ${ }^{10}$

Several nonrandomized studies have suggested that patients with cerebellar hemorrhages $>3 \mathrm{~cm}$ in diameter or patients in whom cerebellar hemorrhage is associated with brainstem compression 
or hydrocephalus have better outcomes with surgical decompression. ${ }^{11-14} \mathrm{~A}$ recent meta-analysis has suggested that u-PA, an alternate thrombolytic, is superior to t-PA for IVH clot evacuation. ${ }^{15}$

To understand underlying causes and natural history of ICH, several studies have been conducted, as well as preclinical studies involving animal models. Spontaneous ICH (not related to trauma), most frequently occurs secondary to hypertension. ${ }^{7}$ This similar found in our study, which higher blood pressure associated with mortality and morbidity. However, ICH may also result from bleeding associated with amyloid angiopathy, tumors, hemorrhagic conversion of ischemic stroke, dural venous sinus thrombosis, vasculitis and vascular marformations. ${ }^{16,17}$

This study showed that higher systolic BP associated significantly with morbidity and mortality, whereas sex and age did not. Seventy-eight percent patients had hypertension when diagnosed with ICH. Broderick et al. ${ }^{14}$ and Zazulia et al. ${ }^{18}$ reported that post - hematoma enlargement causes a midline shift and accelerates neurological deterioration. Mendelow et al. ${ }^{7}$ revealed that nontraumatic ICH most frequently occurs secondary to hypertension, with up to $70 \%$ of patients with ICH having history of hypertension. Ruiz-Sandoval et $a{ }^{17}{ }^{17}$ also reported that hypertension is significant contributory factor for ICH and associated with morbidity and mortality. AHA/ASA guidelines for the management of spontaneous ICH 2015 recommended for ICH patients presenting with systolic BP between 150 and $220 \mathrm{mmHg}$ and without contraindication to acute BP treatment, acute lowering of SBP to $140 \mathrm{mHg}$ is safe (Class I, Level of Evidence A). ${ }^{2}$ It is also mentioned in Neurosurgery National Guideline for Healthcare that $\mathrm{SBP}>180 \mathrm{mmHg}$ or MAP $>130 \mathrm{mmHg}$ with or without increased ICP should give anti-hypertension drug to lowering SBP. ${ }^{19}$ This guideline was used in Neurosurgery Department, Dr. Sardjito General Hospital, Yogyakarta as its clinical standard work pathway.
STICH trial found that comatose (GCS score $\leq 8$ ) patients had increased the risk for a poor outcome ${ }^{7}$. Patients tended to be in a coma (GCS score $\leq 8$ ), did not normalize with medical management. Our observations are consistent with previous study mention above, which comatose patients had higher mortality and unfavorable outcome.

Current recommendations for management of ICH with IVH or hydrocephalus are for ICP monitoring when GCS less than 8 and for ventricular drainage, if there is decreased level of consciousness. Moreover, AHA/ASA recommended patients with a GCS score of $\leq 8$, those with clinical evidence of transtentorial herniation, or those with significant IVH or hydrocephalus might be considered for ICP monitoring and treatment. A CPP of 50 to $70 \mathrm{~mm} \mathrm{Hg}$ may be reasonable to maintain depending on the status of cerebral autoregulation (Class IIb; Level of Evidence C). ${ }^{4}$ In clinical standard work pathway used in Dr. Sardjito General Hospital, neurological deficit, increased ICP, hydrocephalus $>24$ hours and brain stem compression are an indication for surgical evacuation.

The location of an $\mathrm{ICH}$ is important in determining the outcome and potential treatment. Depending on location, bleeding from an ICH may extend into ventricular system. Such intraventricular hemorrhage occurs in $\sim 40 \%$ of ICH patients and predictor of poor outcome. Hanley ${ }^{20}$ reported that spontaneous ICH with IVH is about $42 \%-55 \%$ of cases. IVH is an independent predictor of worse outcomes with mortality rates of $29-78 \%$, compared to $5-29 \%$ for ICH without IVH. This finding was lower in our study, whereas ICH with IVH was account for $24 \%$. However, ICH with IVH was an independent factor associated with higher mortality.

In this study, the LOS for all patients was 12.9 days. Patients who underwent surgery stayed for 1.5 days longer (1.3 times, 14.4 days) than patients who did not (10.9 days). Although there was no different for LOS in surgery or conservative group, however, there was significant difference 
for LOS between died or recover group. Kim et al. ${ }^{4}$ reported who targeted 700,056 cases based on system data from the Korean Hospital Discharge In-Depth Injury Survey, that average LOS being 28.9 days; patient underwent surgery stayed in the hospital on average 9.2 days more (1.4 times, 35.1 days) than patient who did not (25.9 days). However, factors associated with shorter length of stay was not discused in this study.

The limitation of this study was we could not find clear cause of death of hemorrhagic stroke patients, whether hemorrhagic stroke only or other comorbid disease that was diagnosed during hospitalization period.

\section{CONCLUSION}

In conclusion, patients with hemorrhagic stroke who were surgically indicated might have an advantage of hematoma evacuation. The further and more targeted study is needed by incorporating the factors and causes of deaths related to surgical treatment, so that we can obtain more detailed data.

\section{ACKNOWLEDGEMENTS}

We would like to thank all patients who have participated in this study.

\section{REFERENCES}

1. Sacco RL, Kasner SE, Broderick JP, Caplan LR, Connors JJ, Culebras A, et al. An updated definition of stroke for the $21^{\text {st }}$ century. Stroke 2013; 44: 2064-89.

ht tp://dx.doi.org/10.1161/ STR.0b013e318296aeca.

2. Hemphill JC, Greenberg SM, Anderson CS, Becker K, Bendok BR, Cushman M, et al. Guidelines for the management of spontaneous intracerebral hemorrhage: a guideline for healthcare professionals from the American Heart Association/American Stroke Association. Stroke 2015; 46: 2032 60.

h t t p://dx.doi.org/10.1161/ STR.0000000000000069

3. Ibrahim A. Uji klinik kendali acak komparasi penggunaan neuroendoskopi dengn kraniotomi pada evakuasi pendarahan intraserebral spontan. [Dissertation]. Yogyakarta: Fakultas Kedokteran Universitas Gadjah Mada, 2015.

4. Kim SM, Hwang SW, Oh E, Kang J. Determinants of the length of stay in stroke patients. Osong Public Health Res Perpect 2013; 4(6): 329-41.

h t tp://dx.doi.org/10.1016/j . phrp.2013.10.008

5. Mc Kissock W, Richardson A, Taylor J. Primary intracerebral haemorrhage: a controlled trial of surgical and conservative treatment in 180 unselected cases. Lancet 1961; 2: 221-6.

http://dx.doi.org/10.1016/S01406736(61)90353-1

6. Prasad K, Mendelow AD, Gregson B. Surgery for primary supratentorial intracerebral haemorrhage. Cochrane Database Syst Rev 2008; 8(4): CD000200. http://dx.doi.org/ $\quad 10.1002 / 14651858$. CD000200

7. Mendelow AD, Gregson BA, Fernandes HM, Murray GD, Teasdale GM, Hope DT, et al. Early surgery versus initial conservative treatment in patients with spontaneous supratentorial intracerebral haematomas in the International Surgical Trial in Intracerebral Haemorrhage (STICH): a randomised trial. Lancet 2005; 365: 387-97.

http://dx.doi.org/10.1016/S01406736(05)70233-6

8. Mendelow AD, Gregson BA, Rowan EN, Murray GD, Gholkar A, Mitchell PM. Early surgery versus initial conservative treatment in patients with spontaneous supratentorial lobar intracerebral haematomas (STICH II): a randomised trial. Lancet 2013; 382: 397-408.

http://dx.doi.org/10.1016/S 0140 6736(13)60986-1

9. Morgan T, Zuccarello M, Narayan R, Keyl P, Lane K, Hanley D. Preliminary findings of the minimally-invasive surgery plus rtPA for intracerebral hemorrhage evacuation (MISTIE) clinical trial. Acta Neurochirurgica 2008; Supplementum 105: 147-51.

http://dx.doi.org/10.1007/978-3-21109469-3_30

10. Mould WA, Carhuapoma JR, Muschelli J, Lane K, Morgan TC, Mc Bee NA, et al. Minimally invasive surgery plus recombinant tissue-type plasminogen 
activator for intracerebral hemorrhage evacuation decreases perihematomal edema. Stroke 2013; 44: 627-34.

h t t p://dx.doi.org/10.1161/ STROKEAHA.111.000411

11. Da Pian R, Bazzan A, Pasqualin A. Surgical versus medical treatmentof spontaneous posterior fossa haematomas: a cooperative study on 205cases. Neurol Res 1984; 6:145-51.

http://dx.doi.org/10.1080/01616412.1984.1 1739680

12. Firsching $R$, Huber $M$, Frowein RA. Cerebellar haemorrhage: managementand prognosis. Neurosurg Rev 1991;14:191-94. http://dx.doi.org/10.1007/BF00310656

13. van Loon J, Van Calenbergh F, Goffin J, Plets C. Controversies in themanagement of spontaneous cerebellar haemorrhage: a consecutiveseries of 49 cases and review of the literature. Acta Neurochir (Wien) 1993; 122:187-93.

http://dx.doi.org/10.1007/BF01405527

14. Broderick JP, Brott TG, Tomsick T, Barsan W, Spilker J. Ultra-early evaluation of intracerebral hemorrhage. J Neurosurg 1990; 72, 195-99.

ht tp://dx.doi.org/10.3171/ jns.1990.72.2.0195

15. Gaberel T, Magheru C, Parienti JJ, Huttner HB, Vivien D, Emery E. Intraventricular fibrinolysis versus external ventricular drainage alone in intraventricular hemorrhage: a meta-analysis. Stroke 21011; 42 (10): 2776-81.

ht t p://dx.doi.org/10.1161/ STROKEAHA.111.615724

16. Qureshi AI, Palesch YY. Antihypertensive treatment of acute cerebral hemorrhage (ATACH) II: design, methods, and rationale. Neurocritical Care 2011; 15: 559-76. http://dx.doi.org/10.1007/s12028-0119538-3

17. Ruiz-Sandoval JL, Cantu C, Barinagarrementeria F. Intracerebral hemorrhage in young people: analysis of risk factors, location, causes, and prognosis. Stroke 1999; 30(3): 537-41. http://dx.doi.org/10.1161/01.STR.30.3.537

18. Zazulia AR, Diringer MN, Derdeyn CP, Powers WJ. Progression of mass effect after intracerebral hemorrhage. Stroke 1999; 30(6): 1167-73.

http://dx.doi.org/10.1161/01. STR.30.6.1167

19. Persatuan Spesialis Bedah Saraf Indonesia. Pedoman Nasional Pelayanan Kedokteran Ilmu Bedah Saraf. Jakarta: Persatuan Spesialis Bedah Saraf Indonesia, 2016.

20. Hanley DF. Intraventricular hemorrhage: severity factor and treatment target in spontaneousintracerebral hemorrhage. Stroke 2009; 40(4):1533-38.

h t t p ://dx.doi.org/10.1161/ STROKEAHA.108.535419 